$\begin{array}{lll}\text { INTERNATIONAL } & \text { International Journal of Health Services Research and Policy } \\ \text { ENGINEERING, } & 2018-\text { Volume : } 3 \text { Is sue: } 1 \\ \text { SCIENCE AND } & \text { Page: } 1-9 \quad \text { (http://dergipark.gov.tr/ijhsrp) } \\ \text { EDUCATION } & \text { doi: } 10.23884 \text { /ijhsrp.2018.3.1.01 } \\ \text { INESEG } & \begin{array}{l}\text { GROUP } \\ \text { (PUBLISHER) }\end{array} & \text { ISSN: } 2548-0359 \text { e-ISSN: 2602-3482 } \\ & \text { Received: February 03, 2018 Accepted: March 13, } 2018\end{array}$

\title{
THE RELATIONSHIP BETWEEN BAD OBSTETRIC HISTORY AND THROMBOPHILI
}

\author{
Bulat Aytek Sik ${ }^{1}$, Beyhan Badoglu², Serkan Kumbasar ${ }^{3}$, Sedat Bilecan ${ }^{1}$, Yasam Kemal Akpak \\ ${ }^{1}$ Istanbul Aydin University, Department of Obstetrics and Gynecology, Istanbul, Turkey \\ ${ }^{2}$ Istanbul Haseki Education and Research Hospital, Department of Obstetrics and \\ Gynecology, Istanbul, Turkey \\ ${ }^{3}$ Sakarya University, Department of Obstetrics and Gynecology, Sakarya, Turkey \\ ${ }^{4}$ Ankara Dışkapı Yıldırım Beyazıt Training and Research Hospital \\ Department of Obstetrics and Gynaecology, Ankara, Turkey \\ Corresponing author: bulataytek@gmail.com
}

\begin{abstract}
The aim was to evaluate the relationship of recurring miscarriages and in utero mort fetus cases over 20 weeks of pregnancy (except for those caused by a systemic disease or a known pathology) with thrombophilic conditions. Our study was conducted on the patients who were admitted to our clinic with for follow ups or investigation of recurring pregnancy losses. The included patients had had at least 2 fetal losses over 8 weeks into their pregnancy or at least one loss over the 20th gestational week and gave histories of hypertensive pathologies of pregnancy such as preeclampsia or eclampsia. The control group comprised 81 patients who had at least one pregnancy without any complication or fetal loss histories. In our study, the ratios of Factor V Leiden mutation in the study group (106 cases) and the control group (81 cases) were $\% 12$ and $\% 1.3(p=0.01)$ respectively. In the patient group, the MTHFR homozygous mutation was seen 3.3 times as much and Factor V Leiden heterozygous gene mutation was determined to be seen 8.3 as much as the control group. There was a significant difference between the study and control groups in terms of Protein $C$ and S activity $(p<0.0001$ ve $p<0.001)$. In the study group, the detection rate of Protein C levels <\%65 was 5.2 times more(OR 5.2 2.712.49), and the Protein S activity was 12.17 times higher than the control group. Thrombophilic cases may play many roles in the pathologies which arise during pregnancies.
\end{abstract}

Key words: thrombophilia, recurring miscarriages, bad obstetric history

\section{Introduction}

Habitual abortion is one of the issues which is mostly falling short in the determination of etiological and prognostic factors in obstetrics. Sixty eight percent of the recurrent early pregnancy losses are idiopathic. It may be thought that hemostatic mistakes lead to obstruction in placental bed vessels and the changes in the coagulation factors during pregnancy may lead to abortion. For a successful course of pregnancy, an effective uteroplacental circulation is a must and this circulation may be affected by hemostasis disorders. Thus, maternal thrombophilia (Factor V Leiden, Factor II 
mutations, MTHFR \{methylenetetrahydrofolate reductase\} deficiency of Protein C, Protein S) are important pathologies in terms of obstetrics [1].

The tendency to start investigating the reason of recurring miscarriages after the second miscarriage is getting more prevalent. Recurring loss of pregnancy is defined as at least three spontaneous abortions after either the 10th or the 8th gestational week, depending on the source. The reasons are various.

Due to the fact that thrombophilic events are seen in some of the thrombophilic women and not all of them, hereditary thrombophilia is believed to be a multiple gene disease. This may occur due to antithrombin III, protein S or $\mathrm{C}$ deficiency or factor $\mathrm{V}$ Leiden mutations as well as acquired thrombophilias such as the antiphospholipid syndrome [2]. Lately, thrombophilia has been frequently mentioned as the key reason of HELLP syndrome, abruptio placenta, intrauterine growth retardation, inexplicable stillbirth and recurring loss of pregnancy [3].

The aim was to evaluate the relationship of recurring miscarriages and in utero mort fetus cases over 20 weeks of pregnancy (except for those caused by a systemic disease or a known pathology) with thrombophilic conditions

\section{Materials and Methods}

This study was done on 106 women with bad obstetric histories who were admitted to our polyclinic at Haseki Training and Research Hospital Obstetrics and Gynecology Department. between 1st June 2009and 31st December 2012 Bad obstetric history was defined as at least two abortions (loss of pregnancy under the 20th gestational week), at least one in utero mort fetus case over the 20th gestational week or history of preeclampsia. A detailed anamnesis regarding their previous pregnancies was obtained from the patients. Those with any kind of systemic disease, anatomical or organic pathologies regarding the genital system and a known karyotype anomaly were excluded from the study. 81 similar ages patients with at least one history of live birth following a problem-free pregnancy and without any systemic disease, anatomical or organic anomalies of the genital system, history of fetal loss and preeclampsia or a known karyotype anomaly were included in the control group. The patients were informed about the study as well as the benefits regarding the diagnostic and treatment steps. After obtaining their written consents, tests regarding thrombophilia were ordered from the patients. Protein $\mathrm{C}$ activity, protein $\mathrm{S}$ activity, antithrombin III, factor V Leiden mutation, prothrombin gene mutation and MTHFR gene mutation were evaluated. Antithrombin III, Protein $\mathrm{C}$ and $\mathrm{S}$ activities and lupus anticoagulant tests were done with biotech branded, AMAX 200 full automatic coagulation equipment. The reference values of Antithrombin III activity, protein C activity and protein S activity were accepted to be \%70-125, \% 70-130 and \% 55-160 respectively.

In our study, Medcalc statistical program was used for the statistical analyses.In the evaluation of the data, in addition to the descriptive statistical methods (mean, standard deviation), independent ttest, one way variance analysis were used in the comparison of the binary groups; chi-square and odds ratio were used in the comparison of the qualitative data. The results were evaluated in a significance level of $\mathrm{p}<0.05$ and confidence interval of $95 \%$.

\section{Results}

The study group comprised 106 cases who were admitted to our clinic with early and/or late loss of pregnancy and the control group comprised 81 cases without fetal loss. The mean age of the 106 
cases in the study group and 81 cases without any pregnancy complications was $28 \pm 4.9$ and $29.7 \pm 7.4$ respectively. As expected, the number of pregnancies were determined to be significantly higher and the number of live births significantly lower in the study group. (Table 1)

Table1. The comparison of the study and control groups in terms of age, gravida and live births

\begin{tabular}{|l|l|l|l|}
\hline & Study Group & Control Group & P value \\
\hline Age & $28 \pm 4.9$ & & \\
\hline Gravida & $3.5 \pm 1.8$ & $29.7 \pm 7.4$ & 0.06 \\
\hline Live Births & $0.46 \pm 0.71$ & $1.48 \pm 1.28$ & $<0.0001$ \\
\hline
\end{tabular}

In the study group, early loss of pregnancy was seen in 85 cases and one or more loss of pregnancies during the second or third trimesters were seen in 31 cases. The mean gestational week of the late pregnancy losses were determined to be $28.1 \pm 4.8$ in this group.

The rates of MTHFR, Factor V Leiden and Prothrombin multiple gene mutations as well as Protein C, Protein S and Antithrombin III activities were compared between the study and control groups. There was no significant difference between the two groups in terms of MTHFR heterozygous gene mutation, but in terms of MTHFR homozygous form, a significant difference was found.The rate of homozygous mutation was $11.3 \%$ (12 cases) in the study group and $3.7 \%$ ( 3 cases) in the control group ( $\mathrm{P}=0.049)$.. The rate of Factor V Leiden heterozygous gene mutation in the study group was determined to be significantly higher than the control group (12\& vs. $1.3 \%, \mathrm{p}=0.01$ ). Homozygous mutation was not observed in neither of the groups. The number of heterozygous prothrombin gene mutations in the study and control groups was $10(9.4 \%)$ and $3(3.7 \%)$ respectively. The difference was not significant $(\mathrm{P}=0.2)$. We determined the number of cases with a protein $\mathrm{C}$ activity of $<65 \%$ to be significantly higher in the study group ( $\mathrm{P}=0.0003$ ). The number of cases with a protein $\mathrm{S}$ activity of $<65 \%$ were also significantly higher in the study group, but there was no significant difference between the groups in terms of Antithrombin III activity(p:0.000074,p: 1.0). The study and control groups were examined in terms of multiple gene mutations. Multiple gene mutations were detected in 12 cases $(11.3 \%)$ in the study group and 4 cases $(4.9 \%)$ in the control group. The difference was not statistically significant $(p=0.19)$ (Table 2$)$

Table 2. The comparison of the study and control groups in terms of MTHFR, Factor V Leiden and Prothrombin and Multiple Gene Mutations as well as Protein C, Protein S and Antithrombin III activities

\begin{tabular}{|l|l|l|l|l|}
\hline & & $\begin{array}{c}\text { Study group } \\
(\mathbf{n : 1 0 6}) \%\end{array}$ & $\begin{array}{c}\text { Control Group } \\
(\mathbf{n : 8 1}) \%\end{array}$ & P value \\
\hline \multirow{3}{*}{ MTHFR } & Heterozygous & $49(46.2 \%)$ & $33(40.7 \%)$ & 0.5 \\
\cline { 2 - 5 } & Homozygous & $12(11.3 \%)$ & $3(3.7 \%)$ & 0.049 \\
\hline FactorV Leiden & Heterozygous & $10(9.4 \%)$ & $1(1.3 \%)$ & $\mathbf{0 . 0 1}$ \\
\hline
\end{tabular}




\begin{tabular}{|l|l|l|l|l|}
\hline & & & & \\
\hline \multirow{2}{*}{ Prothrombin } & Heterozygous & $10(9.4 \%)$ & $3(3.7 \%)$ & 0.2 \\
\cline { 2 - 5 } & Homozygous & $1(0.94 \%)$ & $0(0 \%)$ & 0.88 \\
\hline Protein C activities & $<\% 65$ & $14(13.2 \%)$ & $1(1.30 \%)$ & 0.00 \\
\hline Protein S activities & $<\% 65$ & $35(33.01 \%)$ & $7(8.6 \%)$ & 0.000074 \\
\hline $\begin{array}{l}\text { Antithrombin III } \\
\text { activities }\end{array}$ & $<\% 75$ & $7(6.6 \%)$ & $5(6.1 \%)$ & 1.0 \\
\hline $\begin{array}{l}\text { MTHFR+Factor V } \\
\text { Leiden }\end{array}$ & $\begin{array}{l}\text { Heterozygous/ } \\
\text { Heterozygous }\end{array}$ & $5(0.47)$ & $1(1.2 \%)$ & 0.23 \\
\hline $\begin{array}{l}\text { MTHFR+ } \\
\text { Protrombin }\end{array}$ & $\begin{array}{l}\text { Heterozygous/ } \\
\text { Heterozygous }\end{array}$ & $7(6.6 \%)$ & $3(2,83 \%)$ & 0.51 \\
\hline
\end{tabular}

The rate of MTHFR homozygous mutation rate was determined as OR 3.3 ( 0.9-12.18), i.e, the possibility of detecting homozygous mutations in the study group was determined to be 3.3 more than that in the control group. The rate of heterozygous Factor V Leiden mutations was 8.3 times more (OR 8.3, 1.04- 66). Homozygous mutations were not seen in either of the groups. In the patient group, the detection rate of Protein C levels $<\% 65$ was 5.2 times more, and the Protein S activity was 12.17 times higher than the control group. (OR 5.2 2.7-12.49, OR:12.17 1.5-94.64) Table 3.

Table 3. Prevalence of thrombophilia

\begin{tabular}{|c|c|c|c|c|c|}
\hline $\begin{array}{l}\text { Type of } \\
\text { thrombophiliaa }\end{array}$ & $\begin{array}{l}\text { Study group } \\
(\mathrm{n}: 106) \\
\text { no. }(\%)\end{array}$ & $\begin{array}{l}\text { Control } \\
\text { group } \\
\text { (n:81) } \\
\text { no. }(\%)\end{array}$ & $\begin{array}{l}\text { Odds } \\
\text { ratio }\end{array}$ & $\begin{array}{l}95 \% \\
\text { confidence } \\
\text { interval }\end{array}$ & $P$ value \\
\hline $\begin{array}{l}\text { MTHFR } \\
\text { (Homozygous) }\end{array}$ & $12(11.3 \%)$ & $\begin{array}{ll}3(3.7 \%) \\
\end{array}$ & 3.3 & $0.9-12.18$ & 0.049 \\
\hline $\begin{array}{l}\text { FactorV } \\
\text { Leiden } \\
\text { (Heterozygous) }\end{array}$ & $10(9.4 \%)$ & $1(1.3 \%)$ & 8.3 & $1.04-66$ & 0.01 \\
\hline
\end{tabular}




\begin{tabular}{|l|l|l|l|l|l|}
\hline $\begin{array}{l}\text { Protein C } \\
\text { activities }\end{array}$ & $14(13.2 \%)$ & $1(1.30 \%)$ & 5.2 & $2.7-12.49$ & $<0.001$ \\
\hline $\begin{array}{l}\text { Protein S } \\
\text { activities }\end{array}$ & $35(33.01 \%)$ & $7(8.6 \%)$ & 12.17 & $1.5-94.64$ & $<0.001$ \\
\hline
\end{tabular}

Mean Protein C, Protein S and antithrombin III activities were evaluated in Table 4. In cases with fetal loss, the Protein $\mathrm{C}$ and $\mathrm{S}$ activities were significantly lower $(\mathrm{P}<0.0001)$ and no significant difference was found in terms of Antithrombin III activity ( $\mathrm{p}=0.47$ ). TABLO:4

Table 4. The comparison of the Study and Control groups in terms of MEAN Protein C, Protein $\mathrm{S}$ and antithrombin III activities

\begin{tabular}{lllc}
\hline & Study & Control & P değeri \\
\hline Protein C activity (\%) & $\mathbf{7 4 . 2} \pm 0.29$ & $95.7 \pm 17.5$ & $<0.0001$ \\
Protein S activity (\%) & $\mathbf{8 6 . 9} \pm 0.23$ & $94.8 \pm 19.4$ & $<0.0001$ \\
Antitrombin III activity (\%) & $96.9 \pm 0.15$ & $98.3 \pm 20$ & 0.47 \\
\hline
\end{tabular}

\section{Discussion}

Pregnancy is an acquired condition during which the thrombogenic activity increases. The changes in the coagulation system due to pregnancy may strengthen the thrombogenic tendency due to hereditary thrombophilia, causing various clinical diseases [4]. Different clinical cases arise due to the pathologies emanating in the placental bed, causing recurring losses of pregnancy, early severe preeclampsia, IUGR, stillbirth and placental pathologies during pregnancy and related complications [5].

Thrombophilia may be hereditary or acquired. The most common cause of the acquired thrombophilia is antiphospholipid antibody syndrome (APA). Deficiency of Protein C, deficiency of Protein S, Antithrombin deficiency, Active protein C resistance (APCR), Prothrombin G20210 mutation, Hyperhomocysteinaemia- MTHFR (Methylenetetrahydrofolate reductase) mutation are among the hereditary thrombophilia

A point mutation in factor $\mathrm{V}$ was shown as the cause of APCR for the first time and this mutation is referred to as 'Factor V Leiden (FVL)'.FVL mutation is the most common cause of hereditary thrombophilia and responsible for $40 \%$ of the thrombosis [6]. FVL heterozygous mutation is seen between the rate of 5 and $10 \%$ while homozygous mutation is seen at a rate of $0.04 \%$ [7, 8]. It is known that homozygous mutations increase the risk of venous thrombosis by 80 times while this risk increased by seven times in in heterozygous carriers [9].

There are conflicting results regarding thrombophilia in severe preclampsia in the literature. While a significant correlation is found between thrombophilia and severe preeclampsia $[10,11,12]$ other pregnancy complications in some studies $[13,14,15]$ there is not any correlation in some others [16].

In Dizon-Townson DS et. al's study done on 158 severy preeclamptic and 403 healthy pregnant women, the rates of Factor V Leiden mutation in the preeclamptic and control groups were determined 
to be $8.9 \%$ and $4.2 \%$ respectively, a significant difference [10]. In the metaanalysis of Linj et. al comprising 31 studies and 7522 patients, the detection rate of Factor V Leiden mutation on all preeclamptic and severely preeclamptic women were 1.81 and 2.24 times higher respectively, which led to the conclusion that Factor V Leiden mutation caused an increased risk of preeclampsia [11].

In the meta-analysis where Rodger et al. evaluated ten prospective studies, there was a significant correlation between FVL mutation and pregnancy losses, but there was not a statistically significant correlation between FVL and prothrombin gene mutations and preeclampsia [13]. Likewise, in the prospective study by Said et al., although a correlation was found between FVL mutation and ablation placenta and stillbirth, no correlation was found with preeclampsia [14]. In a study where Deveer el at. compared 50 patients developing severe preeclampsia and 50 healthy control group, they found FVL mutation carrying at a similar rate and stated that there was not any correlation between thrombophilia and severe preeclampsia [15]. In a study where Kjelberg et al. compared 491 pregnant cases having FVL mutation with 1055 healthy pregnant cases, there was not any correlation between adverse pregnancy outcome and FVL mutation [16].

Among the hereditary thrombophilic factors, we researched the relationship between Protein C activity, protein S activity, antithrombin III, factor V Leiden mutation, prothrombin gene mutation and MTHFR gene mutation's and bad obstetric history in our study.

According to the results we obtained regarding Factor V Leiden gene mutation, there was no homozygous gene mutations in either groups, but the rates of heterozygous Factor V Leiden gene mutation in the study and control groups were $12 \%$ and $1.3 \%$ respectively. The rate of heterozygous gene mutation detection in cases with fetal loss was 8.3 times more (OR 8.3, 1.04- 66). Based on this statistically significant ratio, we determined that Factor V Leiden gene mutation played an important role in the aetiology of recurring losses of pregnancy and late-onset pregnancy complications.

In our study, the rate of heterozygous prothrombin gene mutation in the study and control groups were determined to be $9.4 \%(n=10)$ and $3.7 \%(n=3)$. The difference was not statistically significant $(\mathrm{p}=0.2)$. The homozygous form of the prothrombin gene mutation was detected in 1 case only in the sudy group $(0.94 \%)$ and 0 cases in the control group $(0 \%)(\mathrm{p}=0.88)$. Reznikoff et al. determined the rate of prothrombin $\mathrm{G} 20210 \mathrm{~A}$ mutation to be significantly higher in the study group in their study done on 260 cases with recurring losses of pregnancy under the 10th gestational week and 240 control cases $(2,7$ (\% 95 CI 1-7)) [17].

MTHFR gene mutation is more frequently detected in the population as compared to the other gene mutations. In Foka. Et al's study, the detection rate of MTHFR C677T homozygous mutation in the study and control groups were $8 \%$ and $15 \%$ respectively, therefore they reported that MTHFR mutation could not be a factor in recurring losses of pregnancy [18]. In a similar study done by Pauer et. al, they determined the rate of MTHFR homozygous gene mutation to be $14 \%$ and $12 \%$ in the study and control groups, not finding a statistically significant difference between the two [19].

In our study, the rate of heterozygous MTHFR gene mutation was determined to be $46.2 \%$ and $40.7 \%$ in the study and control groups respectively, revealing a statistically insignificant difference $(\mathrm{p}=0.5)$. The rates of homozygous MTHFR gene mutations in the study and control groups were $11.3 \%$ and $3.7 \%$ respectively and a significant difference was found $(\mathrm{p}=0.049, \mathrm{OR}=3.3)$. It was seen that the possibility of detecting a homozygous MTHFR mutation was 3.3 times more in the study group than in the control group. 
As a result of the analyses on MTHFR gene mutation, it was deduced that the heterozygous form was not clinically significant in terms of pregnancy complications, but the heterozygous form could take on an important role in their development.

Protein S activity decreases by $40-60 \%$ as compared to normal in the first trimester of pregnancy and remains low during the rest [20]. Despite this normal decrease during pregnancy, in our study, the mean Protein S activity of the study group was determined to be much lower than that of the control group. In Kupferminc's study in Israel, published in 2000, the study group was comprised of the severely preeclamptic only and the blood for the detection of Protein S activity was drawn after the second postpartum month, Protein S deficiency was determined to be significantly higher in the study group as compared to the control group [21].

In our study the mean Protein $S$ and Protein $C$ activities of the control group were $95.7 \pm 17.5$ and $94.8 \pm 19.4$ respectively. The same parameters for the study group were $74.2 \pm 0.29$ and $86.9 \pm 0.23$ respectively. The distinct difference in between was statistically significant for both parameters $(p<0.0001, p<0.0001)$. The two groups were compared in terms of Protein $S$ and $C$ activies $<65 \%$ and There was a statistically significant difference in values under $65 \%$ ( $\mathrm{p}$ values for both parameters are $\mathrm{P}=0.0003$ and $\mathrm{P}=0.000074$ respectively). In cases with fetal loss, the detection rate of Protein $\mathrm{C}$ levels $<\% 65$ was 5.2 times more(OR 5.2 2.7-12.49), and the Protein S activity was 12.17 times higher than the control group.

There are conflicting explanations regarding antithrombin III levels in severe preeclampsia. Osmanoğlu et. al reported that antithrombin III deficiency might be used in the prediction of the prognosis and clinical monitorization in preeclampsia [22].

In the study of Ramalakshmi et al., the mean antithrombin III value was determined to be significantly lower in the group with gestational hypertension $[0.76(0.233) \mathrm{IU} / \mathrm{ml} ; 0.97(0.234) \mathrm{IU} / \mathrm{ml}]$ and low levels of antithrombin III were found to ber related to bad pregnancy outcomes [23].

The results of our study are not coherent with the literature. The mean antithrombin III values in the study and control groups are $96.9 \pm 0.15$ and $98.3 \pm 20$ respectively, without a significant difference $(\mathrm{p}=0.47)$. In the comparison between the study and control groups with a cut off value for Antithrombin III activity of $75 \%$ a significant difference was not detected ( $p$ values are $p=1.0$ ).

Scanning women with positive thrombosis conditions in their personal or family histories for FV Leiden and Prothrombin gene mutations is important in the prevention of pregnancy complications. Although thrombophilia has an important role in the etiology of early losses of pregnancy (especially in recurring cases), we do not have enough data to add thrombophilia to the inital evaluation tests for early pregnancy loss. In cases with recurring loss of pregnancy, late pregnancy complications (IUMF, preeclampsia and complications) and positive history of thrombosis, evaluation of the thrombophilic base will prove beneficial in terms of both diagnosis and treatment.

\section{REFERENCES}

[1] Preston F, Rosendaal F, Walker ID et al. İncreased fetal loss in women with heritable thrombophilia. The Lancet 1996 ;348(5): 913-916. 
[2] Dizon- Townson D, Meline L, Nelson LM, Varner M, Ward K. Fetal carriers of the factor $\mathrm{V}$ Leiden mutation are prone to miscarriage and placental infarction. Am J Obstet Gynecol 1997; 177:402-5.

[3] Kupferminc M, Eldor A, Steinman $\mathrm{N}$ et al. Increase frequency of genetic thrombophilia in women with complications of pregnancy. N Engl J Med 1999; 340:9-13. DOI: 10.1056/NEJM199901073400102

[4] Franco C, Walker M, Robertson J, et al. Placental infarction and thrombophilia. Obstet Gynecol 2011;117(4):929-38. doi: 10.1097/AOG.0b013e31820ca040.

[5] Mousa HA, Alfirevic Z. Do placental lesions reflect thrombophilia state in women with adversepregnancy outcome? Hum Reprod 2000;15(8):1830-3.

[6] Aznar J, Villa P, Espana F, Estelles A, Grancha S, Falco C. Activated protein C resistance phenotype in patients with antiphospholipid antibodies. J Lab Clin Med 1997;130(2):202-8.

[7] Lykke JA, Bare LA, Olsen J et al. Thrombophilias and adverse pregnancy outcomes: results from the Danish National Birth Cohort. J Thromb Haemost 2012;10(7):1320-5. doi: 10.1111/j.15387836.2012.04773.x.

[8] Kabukcu S, Keskin N, Keskin A, Atalay E. The frequency of factor V Leiden and concomitance of factor V Leiden with prothrombin G20210A mutation and methylene tetrahydrofolate reductase C677T gene mutation in healthy population of Denizli, Aegean region of Turkey. Clin Appl Thromb Hemost 2007;13(2):166-71. DOI:10.1177/1076029606298990

[9] Spina V, Aleandri V, Morini F. The impact of the factor V Leiden mutation on pregnancy. Hum Reprod Update 2000;6(3):301-6.

[10] Dizon-Townson DS, Nelson LM, Easton K, Ward K. The factor V Leiden mutation may predispose women to severe preeclampsia. Am J Obstet Gynecol. 1996 Oct;175(4Pt-1):902-5.

[11] Lin J, August P. Genetic thrombophilias and preeclampsia: a meta-analysis. ObstetGynecol. 2005 Jan;105(1):182-92. DOI:10.1097/01.AOG.0000146250.85561.e9

[12] Mello G, Parretti E, Marozio L, et al. Thrombophilia is significantly associated with severe preeclampsia: results of a large-scale, case-controlled study. Hypertension 2005;46(6):1270-4. https://doi.org/10.1161/01.HYP.0000188979.74172.4d

[13] Rodger MA, Betancourt MT, Clark P, et al. The association of factor V leiden and prothrombin gene mutation and placenta-mediated pregnancy complications: a systematic review and metaanalysis of prospective cohort studies. PLoS Med 2010;7(6):e1000292. doi: 10.1371/journal.pmed.1000292.

[14] Said JM, Higgins JR, Moses EK, Walker SP, Monagle PT, Brennecke SP. Inherited thrombophilias and adverse pregnancy outcomes: a case-control study in an Australian population. Acta Obstet Gynecol Scand 2012;91(2):250-5. DOI:10.1111/j.1600-0412.2011.01293.x

[15] Deveer R, Engin-Ustun Y, Akbaba E, et al. Association between Pre-eclampsia and inherited thrombophilias. Fetal Pediatr Pathol 2013;32(3):213- 7. doi: 10.3109/15513815.2012.721475. 
[16] Kjellberg U, van Rooijen M, Bremme K, Hellgren M. Factor V Leiden mutation and pregnancyrelated complications. Am J Obstet Gynecol 2010;203(5):469.e1-8. doi: 10.1016/j.ajog.2010.08.011.

[17] Reznikoff-Etievan MF, Cayol V, Carbonne B, Robert A, Coulet F, Milliez J: Factor V Leiden and G20210A prothrombin mutations are risk factors for very early recurrent miscarriage. BJOG 2001, 108(12):1251-1254

[18] Foka ZJ, Lambropouloos AF, Saravelos H, et al: Factor V leiden and prothrombin G20210A mutations, but not methylenetetrahydrofolate reductase $\mathrm{C} 677 \mathrm{~T}$, are associated with recurrent miscarriages. Hum Reprod,2000, 15(2):458-62.

[19] Pauer HU, Voigt-Tschirschwitz T, Hinney B, et al: Analyzes of three common thrombophilic gene mutations in German women with recurrent abortions. Acta Obstet Gynecol Scand 2003, 82(10):942-7.

[20] Sayin M, Varol FG, Sayin NC. Evaluation of natural coagulation inhibitor levels in various hypertensive states of pregnancy. Eur J Obstet Gynecol Reprod Biol. 2005 May. DOI: 10.1016/j.ejogrb.2005.03.020

[21] Kupferminc MJ, Fait G, Many A, Gordon D, Eldor A, Lessing JB. Severe preeclampsia and high frequency of genetic thrombophilic mutations. Obstet Gynecol 2000, 96:45-9

[22] Osmanagaoglu MA, Topcuoglu K, Ozeren M, Bozkaya H. Coagulation inhibitors in preeclamptic pregnant women. Arch Gynecol Obstet 2005, 271(3):227-30. DOI:10.1007/s00404$\underline{003-0596-4}$

[23] Ramalakshmi, B A. Raju, L A. Raman, L. Antithrombin levels in pregnancy induced hypertension. National Med Jour of İndia 1995, 8(2):61-2. 